\title{
SAHRIS: USING THE SOUTH AFRICAN HERITAGE REGISTER TO REPORT, TRACK AND MONITOR HERITAGE CRIME
}

\author{
K. Smuts \\ National Inventory Unit, South African Heritage Resources Agency, \\ PO Box 4637, Cape Town 8000, South Africa - ksmuts@sahra.org.za
}

KEY WORDS: SAHRIS, heritage crime, objects, museum, digitization, integration

\begin{abstract}
:
South Africa has experienced a recent increase in thefts of heritage objects from museums and galleries around the country. While the exact number of incidences is not known, the increase in thefts is nonetheless apparent, and has revealed the weaknesses of the systems currently in place to respond to these crimes. The South African Heritage Resources Information System (SAHRIS) is an integrated, online heritage resources management tool developed by the South African Heritage Resources Agency (SAHRA) in 2011 in terms of Section 39 of the National Heritage Resources Act (NHRA), No. 25 of 1999. The system's combined heritage resources and site and object management functionality has been expanded to provide an integrated, responsive tool for reporting heritage crimes and tracking the progress of the resultant cases. This paper reviews existing legislative frameworks and crime reporting and monitoring systems relevant to fighting heritage crime, and identifies current gaps in those responses. SAHRIS is presented as an innovative tool to combat heritage crime effectively in the South African context by offering a centralised, consolidated platform that provides the various stakeholders involved in reporting heritage crimes and locating and retrieving stolen objects with a means to coordinate their responses to such instances.
\end{abstract}

\section{INTRODUCTION}

With South African artworks enjoying ever rising prices (Bester, 2013), and the commemoration of centenaries and other anniversaries of significant historical events, such as the outbreak of World War I, serving to stimulate the demand for illicitly acquired heritage objects, heritage crime has been on the rise in South Africa (Benson, 2013). Globalisation has also made it simpler to trade in heritage objects sourced from around the world (Ramskjær, 2011; Brodie et al, 2000).

South African museums, which are often underfunded and short staffed, are seldom equipped with adequate security measures in terms of personnel and equipment, making them soft targets for heritage crime, both in the form of opportunistic theft by individuals or sophisticated, targeted operations by crime syndicates (Benson, 2013).

Affected repositories tend to be reactive and defensive in responding to these incidences, with some closing temporarily in the wake of such incidences (see SAPA 2012; Associated Press 2012), and others removing the remaining vulnerable or valuable heritage objects from display (e.g. Hollands, 2014). While these reactions do serve to protect those heritage objects which are moved to secure storage, or simply no longer available for viewing, negatively affect the institutions as these heritage objects are often those that generate the most visitor interest and revenue.

A further problem arises from the way heritage crimes are processed by the South African Police Services (SAPS), which obscures how pervasive this problem truly is by not recording heritage crime as distinct from other kinds of crime (Benson, 2013). The investigation of heritage crimes currently falls under the purview of the SAPS Endangered Species Protection Unit (ESU), which is also mandated with combating South Africa's rampant rhinoceros poaching (Benson, 2013), negatively impacting the resources available to the processing of heritage crimes.

The South African Heritage Resources Agency, (SAHRA) is a statutory body established in terms of the National Heritage Resources Act (NHRA), No. 25 of 1999 (South Africa, Dept. of
Arts and Culture, 1999a), which is responsible for the identification, management and protection of the country's heritage resources. SAHRA developed the South African Heritage Resources Information System (SAHRIS) in 2011, to assist it to fulfill its mandated functions. SAHRA has long been identified as a key role player in the fight against heritage crime (Memela, 2008), and SAHRIS provides a means by which SAHRA can fulfill this role and offer assistance in the fight against illicit trade in heritage objects.

\section{INTERNATIONAL RESPONSES TO HERITAGE CRIME}

\subsection{International Conventions}

Heritage crime is neither a new phenomenon, nor restricted to South Africa. Indeed, the international heritage community has long been aware of the vulnerability of heritage resources to theft and illegal damage. This awareness has found its expression in numerous international conventions, which are central to guiding policy amongst their various signatories.

The earliest of these international conventions was the Hague Convention for the Protection of Cultural Property in the Event of Armed Conflict of 1954 (The Hague, 1954), which, together with the second Protocol to the 1954 Hague Convention, was ratified in 1999 (The Hague, 1999). The 1954 Hague Convention was built on two earlier conventions related to acts mainly of destruction, perpetrated predominantly against immovable heritage during wartime, but extended this protection to all objects of cultural heritage under threat from unrest both internal or international (Benson, 2013). The Second Protocol affords extended protection to sites of World Heritage Site or similar status (The Hague, 1999).

This was followed by the promulgated UNESCO 1970 Convention on the Means of Prohibiting and Preventing the Illicit Import, Export and Transfer of Ownership of Cultural Property (Paris, 1970), only later ratified in 2003 by South Africa.(Benson, 2013). This legal instrument was chiefly concerned with putting in place measures to curb the illegal trade in heritage objects and is, according to Benson, 2013), 
"considered both a cornerstone of cultural heritage law and a watershed date for provenance assessments". In 1972, the UNESCO Convention concerning the Protection of the World Cultural and Natural Heritage (Paris, 1972) allowed for the drafting of a list of World Heritage Sites.

In 1995, the Institute for the Unification of Private Law (UNIDROIT), promulgated the Convention on Stolen or Illegally Exported Cultural Objects (Rome, 1995), a convention intended to supplement, but not override the 1970 UNESCO Convention (Benson, 2013). This later convention provided for the restitution of stolen or illegally exported heritage objects.

It was only in 2001, that the UNESCO Convention on the Protection of Underwater Cultural Heritage (Paris, 2001) was signed into effect to protect shipwrecks and associated materials, and also regulate salvage operations (Benson, 2013).

Following on from the above international conventions, which all deal with tangible heritage, only two conventions addressed issues related to intangible heritage. These were the UNESCO Convention for the Safeguarding of the Intangible Cultural Heritage (Paris, 2003) and the Convention on the Protection and Promotion of the Diversity of Cultural Expression Paris, 2005) (Benson, 2013). The 2003 Intangible Cultural Heritage Convention was designed to complement the UNESCO Convention of 1972, providing recognition for oral traditions, while the 2005 Convention sought to protect art in international trade (Benson, 2013).

The terms of these conventions are binding for all signatories, and assist those countries to direct their own heritage management legislation.

\subsection{International Heritage Bodies}

Internationally, preventative measures have long been in place to curb instances of heritage crime. The International Council of Museums (ICOM) was established in 1946, and has proved a formidable role player in the fight against heritage crime around the world. ICOM provides support and assistance to more than 32000 museum professionals in 20000 museums around the world (ICOM, 2014). One of the 31 international committees constituted under ICOM is the International Committee on Museum Security (ICMS) - which was established in 1974 (ICMS, 2010). The ICMS Handbook on Emergency Procedures provides a framework for risk management at museums, incorporating responses to theft and vandalism (Hekman, 2010).

In the United Kingdom, the issue of heritage crime is administered by Historic England, the public body that works with English Heritage to manage England's Historic Environment (Historic England, 2015a). Historic England reported that there were an estimated 75000 occurrences of heritage crime in the United Kingdom 2011 (see Bradley et al, 2012). These crimes included metal theft, vandalism, graffiti and arson, and affected one in eight protected sites (Hough \& Beckford, 2012). Historic England, in association with the Alliance for Reduction of Crime against Heritage (ARCH) has adopted a proactive approach to dealing with heritage crime, combining intensive community involvement with upto-date research on the occurrence of offences (Harrison, 2013; Historic England, 2015b). ARCH, which was established in 2011, comprises volunteers from across the country who undertake to address heritage crimes, generate local interest and stimulate local action as part of the Heritage Crime Programme (Historic England, 2015b).

Historic England, furthermore, provides comprehensive information and advice on what constitutes heritage crime and what the public can do when such instances come to light (Historic England, 2015c; Historic England, 2015d). Accessible online resources provide updates on recent occurrences of heritage crime, as well as the outcomes of those criminal cases that have been prosecuted. Police involvement is advised as the first step in reporting heritage crime, by means of phoning the national police hotline (Historic England, 2015d), and the emphasis by Historic England is on multi-agency responses. To this end, they have signed a Memorandum of Understanding (MOU) with the police through the Association of Chief Police Officers (ACPO), as well as the Crown Prosecutions Service, and local authorities (Historic England, 2015d) that allows for the sharing of information and skills, as well as collaboration between the signatories (Grove, 2013).

The involvement of law enforcement in heritage crimes is also well-established internationally. According to INTERPOL and the Federal Bureau of Investigation (FBI) (AP, 2012), for example, art theft is recorded as the third most lucrative crime in the world, after drugs and illicit arms sales. Possibly as a result of the recognition of this fact, the investigation of heritage crime is quite often conducted by dedicated crime units in other countries. This is the case at the FBI in the United States, the Metropolitan Police in the United Kingdom and INTERPOL (Benson, 2013).

INTERPOL has maintained a list of trafficked heritage objects in the Stolen Works of Art Database since 1947 (INTERPOL, 2015a). The general public can access information about the most recently stolen heritage objects, recovered objects and objects still not claimed by their owners (Ibid). In addition, the public can access the ICOM Red Lists, which detail critically vulnerable heritage objects, particularly from areas of conflict, and include African Archaeological Objects, Iraqi and Afghanistan Antiquities and others (ICOM, 2015a). Law enforcement agencies and members of the public who have applied for specific rights can access additional information to that which is publicly accessible. The website also provides a guide to the international standard for describing heritage objects, known as Object ID, in order to facilitate their identification in the event of theft (INTERPOL, 2015b). Like Historic England, INTERPOL emphasizes the need for collaborative approaches to curbing heritage crime, a lesson, which can be followed by similar organizations in South Africa.

A comparable list is maintained by the Metropolitan Police, in the form of the London Stolen Arts database, which contains records of almost 60000 stolen artworks and heritage objects (Anon, 2015). The database is searchable on request, and the Object ID form is available for owners of objects to record and capture their stolen possessions on the system.

Similarly, the FBI's dedicated Art Crime Team consists of 15 agents, supported by three attorneys, and maintains the National Stolen Art File (NSAF), which lists both stolen art and objects (FBI, N.D.a). The NSAF is international in its scope as it reports several cooperative "sting" operations across the world (FBI, N.D.b). The FBI website allows for reporting crimes online, and provides contact details for FBI offices (Ibid).

All of these resources have commonalities. They provide online databases of stolen heritage objects, and all provide advice on, 
or links to the appropriate law enforcement bodies for reporting the crimes. However, the degree of public access is variable, and, in some cases selective, and most of these databases are simply repositories of information about stolen objects. These repositories are isolated and disparate, and there is no relational, integrated platform for cooperation between relevant role players and stakeholders.

\section{SOUTH AFRICAN RESPONSES TO HERITAGE CRIME}

\subsection{South African Legislation}

The mandate for fighting heritage crime in South Africa is enshrined in the National Heritage Resources Act, No. 25 of 1999 (NHRA) (South Africa, Dept. of Arts and Culture, 1999a). SAHRA was constituted under the NHRA and is responsible for identifying and managing all heritage resources in the country.

The NHRA describes what constitutes a heritage object and the conditions under which these might be traded, bought or sold, as well as the import and export of nationally significant heritage objects (South Africa, Dept. of Arts and Culture, 1999a). The repatriation of significant heritage resources to South Africa is also under the mandate of SAHRA, in terms of Section 13(2)iv of the NHRA (South Africa, Dept. of Arts and Culture, 1999a). Section 39 of the NHRA (South Africa, Dept. of Arts and Culture, 1999a) mandates SAHRA with the creation and maintenance of a heritage register of the national estate, managed by the SAHRA National Inventory Unit. Section 51 of the NHRA provides the framework for the penalties prescribed for contraventions of the Act, which can include fines, imprisonment and confiscation of assets (South Africa, Dept. of Arts and Culture, 1999a).

A second piece of legislation, the National Heritage Council Act, No. 11 of 1999 (South Africa, Dept. of Arts and Culture, 1999b), established the National Heritage Council (NHC), which functions as a policy advisory body and public awareness campaigner responsible for funding heritage initiatives (Benson, 2013). In partial overlap with SAHRA's mandate, the $\mathrm{NHC}$ is responsible for effective repatriation of heritage resources held overseas, although the role of the NHC in repatriation can be viewed as providing a policy framework, while SAHRA's role is one of active implementation of the repatriation process (Benson, 2013).

Both of these bodies fall under the remit of the South African National Department of Arts and Culture (DAC), and are assisted in fulfilling their functions by several other bodies and professional associations.

\subsection{South African Heritage Bodies}

A community of professional associations assists government bodies to fight heritage crime by developing museum and heritage policies and guidelines, and providing support and assistance in the implementation of those strategies.

The South African Museums Association (SAMA) was established in 1936 to promote museology and heritage practice in South Africa, and is active in local initiatives against heritage crimes (SAMA, 2015a). SAMA's professional standards promote best practice amongst their members (SAMA, 2006) and signing the ICOM code of ethics is compulsory for all members (SAMA, 2015b). SAMA conducts regular workshops around the issue of heritage crime and distributes news of heritage crime amongst its members (Benson, 2013).

The National Forum for the Law Enforcement of Heritage Related Matters (NALEH), though currently non-functional, was an effective forum comprising members of the Endangered Species Unit (ESU) of SAPS, the Department of Arts and Culture (DAC), the INTERPOL National Central Bureau, Pretoria, SAHRA, SAMA, ICOM-SA - the South African branch of ICOM, which is detailed below - and the National Heritage Council (NHC). NALEH's objectives are wide ranging and ambitious, including facilitating cooperation between the heritage sector and law enforcement sectors, generating policy and sharing information around heritage crime as well as providing training to the heritage sector, law enforcement and customs officials (Benson, 2013).

Governmental and professional agencies and associations are not the only group with a vested interest in protecting heritage objects. Commercial organizations, such as auction houses, galleries and others involved in the trade of heritage objects, can make meaningful contributions to the fight against illegal trafficking. A useful initiative was begun by art underwriters known as, Artinsure, who established a database of stolen heritage objects that is accessible online at www.artinsure.co.za (Artinsure, 2012). While this resource was started as an administrative tool for the company and its clients, it has expanded to include items that are not insured by the company. In 2014, an agreement was reached between Artinsure and SAHRA to share their data reciprocally to ensure that this information is centralized and up to date.

The question then arises, to what extent do South African museums and galleries make use of the local and international systems and organizations available to them in the event of heritage crime. In Benson (2013), the results of a survey of a small sample of museums showed that while 83 percent of respondents had specific guidelines in place for reporting theft/loss, these ranged widely from institution to institution. Measures in place included reporting the theft to their boards, informing auction houses and galleries of the thefts, and informing their insurance companies (Benson, 2013). Some institutions reported the thefts to specific websites, although both websites identified are commercial websites $\underline{w w w . a r t i n s u r e . c o . z a}$, and www.artloss.com, an international, private database of stolen objects that offers its services at a fee. None of the institutions canvassed used the INTERPOL Stolen Works of Art Database, and relatively few reported the thefts to the police (Benson, 2013). The underreporting of heritage object theft from repositories is an internationally recognised problem, and reasons, in the South African survey, ranged from the institution relying on the stolen heritage turning up, to the theft not being successful (Benson, 2013).

\section{GAPS IN THE APPROACH TO HERITAGE CRIME}

\subsection{Identifying the Gaps}

Locally, the problems in responding to and curbing heritage crime can be identified variously as underreporting, inadequate policing, the low priority of heritage crime in a country that suffers high violent crime rates, lack of public awareness of heritage and under resourcing of museums that have poor security and insufficient, undertrained staff (Benson, 2011). 
These issues exist, to varying degrees around the world (Grove, 2013; Dobovšek \& Slak, 2011). However, a larger problem plagues the effective containment of heritage crime: the general lack of centralised heritage databases that serve as digital repositories as well as platforms for cooperation and synchronisation of the role-players and stakeholders in fighting heritage crime (Harrison, 2013; Historic England, 2015b; INTERPOL 2015b). While the need for this is recognised by all involved in the fight against heritage crime, there seem to have been no steps taken to address this gap.

\subsection{Collaboration and Innovation}

Benson (2013) discusses the prevalence of heritage crime in Gauteng, South Africa and proposes initiatives that will address the gaps she identifies. Benson (2013) recommends the establishment of a South African database of stolen heritage objects, which correlates with the INTERPOL Stolen Works of Art Database and can be cross checked for compliance with the Second-Hand Goods Act, No 6 of 2009 (South Africa, 2009). Benson (Ibid) further calls for the development of a central repository, which collates heritage crime data for analysis to detect crime trends and notify role players of these. Benson's (Ibid) final suggestion is the establishment of a network for the case investigators, comprising insurance underwriters, museum and gallery security managers and relevant specialists in the field. Benson (2013) significantly suggests that for NALEH to be reconstituted and to function effectively, it requires the establishment of a formal repository and inclusion in the formal structure of either SAPS or SAHRA.

This call for collaborative responses to heritage crime is echoed internationally by Historic England, INTERPOL and the FBI. Indeed, Historic England and ACPO make explicit the need for "law enforcement, heritage sector and auction house/antiques/architectural salvage trade professionals" to coordinate intelligence databases and search facilities "to support 'due diligence' inquiries at points of sale and transfer of heritage assets" and further highlights the "need to undertake a clear and accurate inventory of items both on, and off, display" as a tool in the prevention and detection of heritage crime (ACPO, 2013).

This local and international research clearly delineates the need for coordinated, centralized databases that assist with identification of stolen objects, link the relevant role players and provides up to date information on the status of cases. In developing the South African Heritage Resources Information System (SAHRIS), SAHRA has created an integrated, centralized database and repository that facilitates collaborative cooperation between role players, and that addresses the gaps in the fight against heritage crime identified by researchers within South Africa and more widely.

\section{CLOSING THE GAP: THE SOUTH AFRICAN HERITAGE RESOURCES INFORMATION SYSTEM (SAHRIS)}

\subsection{An overview of SAHRIS}

The South African Heritage Resources Information System (SAHRIS) is a free, open source, web-based heritage management system built on the Drupal Content Management System and Geoserver (Wiltshire, 2013).

Firstly, SAHRIS functions as an integrated heritage management system, in terms of the relevant sections of the NHRA, allowing for the online processing of permits, impact assessments, surveys, gradings and declarations. Secondly, the system serves as a national heritage sites repository, securely storing information for all sites recorded in heritage registers and research collections around South Africa. Thirdly, SAHRIS provides a collections management suite, capturing object descriptions, histories and photographs and further, offering integrated permitting processes to govern the import and export of heritage objects, inter-museum movement, conservation treatments and other features (Wiltshire, 2013).

Following the launch of the ICOM International Observatory on Illicit Traffic in Cultural Goods and growing evidence for the increase of instances of theft of heritage objects (ICOM, 2015b), the system was expanded to facilitate the recording of heritage crimes in South Africa. This was achieved by increasing the system's functionality to bridge its existing heritage management processes and its collections management suites of features.

SAHRA recognises that the creation and maintenance of comprehensive, up to date digital inventories, with descriptions and photographs of the objects, is critical in the fight against heritage crime (ACPO, 2013; Korsell et al, 2006; ICMS/ICOM, 1993). These inventories allow repositories to keep precise records of their holdings and thereby establish more quickly that items have been stolen or lost. They also ensure the positive identification of the objects should they be recovered, and stand as proof of ownership of the objects (Benson, 2013), which can lead to more successful prosecutions, and thereby serve as a deterrent to criminals.

Two programmes assist SAHRA with the roll out of SAHRIS to museums and galleries in South Africa. The first of these is the National Audit Project, which is managed by the SAHRA National Inventory Unit, and assists museums and galleries to digitise their records, photograph their objects and upload their digitised inventories onto SAHRIS. The Project funds audits of institutions with vulnerable and poorly documented collections, and also provides free training and data storage to any other state repositories. The second programme dovetails with the GRAP103 accounting standard implemented by National Treasury that requires all state institutions to determine the value of the heritage assets in their possession (National Treasury, 2014). Institutions can conduct their audits making use of the SAHRIS object import template, which makes provision for the valuing of objects, or the existing institutional databases can be manipulated to the appropriate format for import into SAHRIS (Jackson, 2015). The system will, by default, keep all valuations and locations of objects private from the public.

Having established what SAHRIS is, we can now look at the ways in which the heritage crime functionality of the system addresses the gaps identified in responses to heritage crimes.

\subsection{Maximising SAHRIS' Potential}

The system allows users to create heritage objects that are recorded in full, and are captured in compliance with the required descriptive fields of the INTERPOL Object ID form, recording all the available descriptions, dimensions, photographs and other information relevant to the heritage object. These objects can be created singly, or entire databases can be uploaded by means of an Excel spreadsheet. 


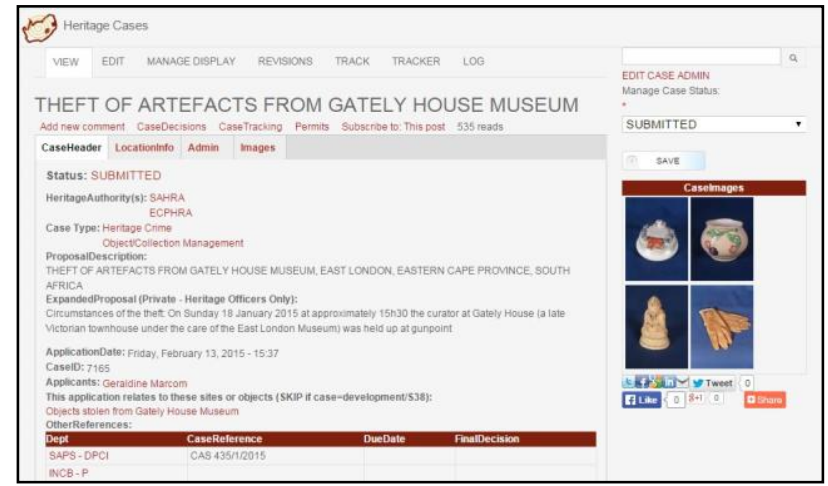

Figure 1: Example of a heritage crime case on SAHRIS

Once digitised, these objects can then be linked, through the creation of a Heritage Crime Case application, to the details of the crime perpetrated. The case also captures, and links, the repository from which they were stolen and its geographical location as well as all role players involved, be they government heritage officers; museum officials; heritage practitioners; local and/or international law enforcement officers; art dealers; Customs Officials and the public.

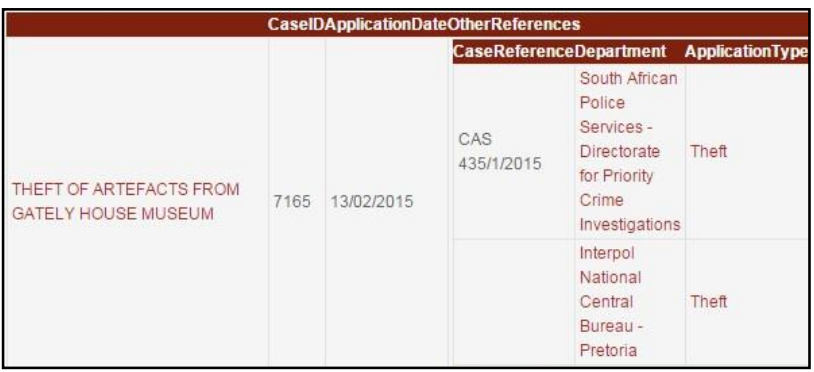

Figure 2: Example of police officer's dashboard

The details of the criminal case are captured, including the police case numbers, linking the SAHRIS case to the police databases. Any of the various branches of law enforcement can be separately indicated, for instance the SAPS Directorate for Priority Crime Investigation (DCPI) under which the ESU falls, as well as the INTERPOL National Central Bureau, Pretoria (INCB-P). All role players who have registered a free account with SAHRIS can log in directly to SAHRIS and view the case on their own dashboard.

SAHRIS makes provision for a full description of the case, which is publicly accessible, while, if deemed necessary by the case author, further case details can be captured to a secure field when creating the case. This features allows SAHRA to fulfil its duties in terms of facilitating public access to information while still ensuring that sensitive information is kept private so as to not jeopardise investigations or compromise individuals' rights to privacy. Similarly the object and the affected repository can both be kept private, visible only to members of the group audience created for that specific case, while the location of objects within repositories is always private by default.

Once the case is created, it is publicly viewable to anyone with access to the internet, including via mobile platforms. Any member of the public who registers on SAHRIS is also able to comment on any case. In the instance of heritage crimes, this comment could be in the form of information relevant to the case, tip-offs or leads.
The system allows users to search for all heritage crimes listed, as well as produce a list of all objects flagged as stolen. This function provides the first opportunity in the country to begin to assess the extent of heritage crime, as well as the capacity to map the location at which the crime occurred, which has significant ramifications. Benson $(2013 ; 2011)$ identifies that one of the drivers of heritage crime is the location of museums and galleries in "hot spot" areas, that is, areas recognised to have high general crime levels. "Hot spot" mapping is a central tenet of modern policing, and is proven as an effective method in preventing crime (Eck et al, 2005). This practice entails recognising the areas where different types of crimes are more prevalent and providing appropriate levels of proactive policing.

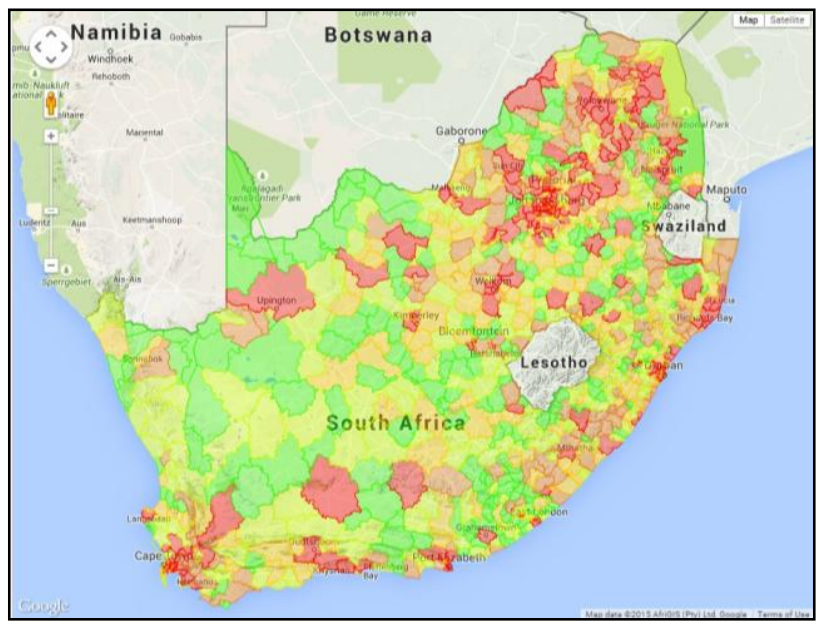

Figure 3: SAPS crime "hot spot" map of South Africa (ㄷ 2014 Crime Stats SA)

While, as has been indicated, heritage crimes are not captured separately from other kinds of crimes, SAPS does record "hot spot" maps of crime across the country (Benson, 2013). The built-in mapping function of SAHRIS and the capacity to generate GIS overlays means that locations of crimes captured and mapped on SAHRIS can be measured against the SAPS "hot spot" maps.

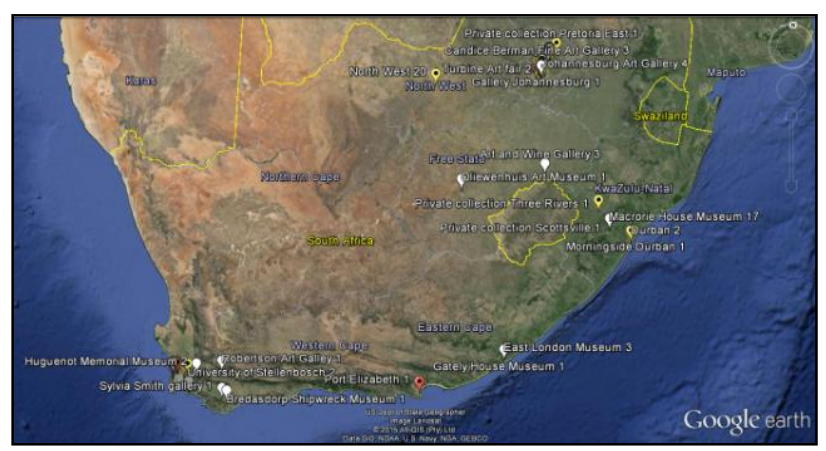

Figure 4: Mapped incidences of heritage crime in South Africa indicating location of crime and number of incidences (ㄷ) 2015 Google Earth)

Given the low profile of heritage crimes in South Africa compared to violent crimes generally, and the specific factor of their competition for police resources with wildlife poaching, the capacity to generate accurate, heritage specific, composite 
maps of this nature could serve to channel the limited resources of SAPS and the heritage fraternity into successful preventative measures. Raising awareness of these crimes is a vital step in ensuring this matter is appropriately and adequately prioritized by museum practitioners and law enforcement agencies (Korsell et al, 2006).

The system, therefore, fulfils the functions highlighted as necessary by both local and international members of the heritage community to address the issue of heritage crime. By virtue of its being freely available and accessible online, SAHRIS serves as a central repository for information related to heritage crime. As a one-to-many relational database, SAHRIS serves to link all role players engaged in the process of recording, investigating and even, ultimately prosecuting, heritage crimes, it provides a cooperative network for engagement. Ultimately, the capacity of SAHRIS to aggregate statistics and location information and create reports on that data will allow the system to increase intelligence on the perpetration of heritage crimes, where the crimes occur, their increase or decrease through time, the percentage that are resolved and the outcomes of prosecutions.

\section{CONCLUSION}

In conclusion, this paper has presented some of the issues surrounding heritage crime in South Africa and the reactions to the threat by affected organizations, institutions and the police service. International standards and methods of reporting and tracking these crimes have been reviewed. SAHRIS has been proposed as a platform that can serve to capture critical details about instances of heritage crimes in South Africa. This tracking tool allows the necessary linkage of the stolen heritage objects, to the affected institution and the role players involved in each step of the process, from opening the case, investigating

\section{REFERENCES}

Anon., 2015. London Stolen Arts Database. Mayor's Office for Policing and Crime,

http://content.met.police.uk/Article/London-Stolen-Artsdatabase/1400011390417/1400011390417 (11 March 2015).

Artinsure, 2012. Artinsure, http://www.artinsure.co.za/ (19 June 2015).

Associated Press, 2012. Art theft: Overseas shopping list? News24. 12 November, http://www.news24.com/SouthAfrica/News/Art-theftOverseas-shopping-list-20121112 (3 October 2013).

Association of Chief Police Officers, 2013. Heritage and cultural property crime: national policing strategic assessment, http://www.museumsassociation.org/museumsjournal/news/19112013-police-national-strategy-heritagecrime (3 October 2014).

Benson, B.C., 2013. Addressing Heritage Crime in Gauteng, South African: an integrative exposition. Unpublished $\mathrm{PhD}$ Thesis, University of South Africa, Pretoria http://uir.unisa.ac.za/bitstream/handle/10500/13055/Phd\%20 Benson\%20FINAL\%20cover $\% 20$ and $\% 20$ body $\% 20$ after\%20exam\%202013-0826.pdf?sequence=1 (15 July 2014). the case, to convicting the perpetrator. The system collates all this information in a single database that is easy to use and that can generate data about heritage crimes for reproduction and comparative analysis in South Africa.

The digitisation of the country's heritage collections is of enormous importance for the purpose of preserving these valuable and often irreplaceable heritage objects in a digital and accessible format. When one further considers how vulnerable these heritage objects clearly are to theft and destruction, this process becomes even more fundamentally essential for the protection of South Africa's heritage resources. The existence of this system provides a free repository for museums in the process of digitising their collections, whether as part of general collections management practice or, more specifically, for compliance with GRAP103.

Any heritage object already recorded on SAHRIS, together with details regarding its appearance, size, composition, inscriptions and notable markings, together with comprehensive photographs, stands a far greater chance, should it be stolen, of being located, positively identified and restored to its original position in the institution from which it was removed. The successful return of these heritage objects and prosecution of the perpetrators will serve as a deterrent for heritage crime going forward. The network generated by the SAHRIS system, linking the stakeholders, including government agencies, museum professionals, heritage practitioners, art dealers and law enforcement officials, involved in the reporting, investigating and prosecution of the case, as well as the general public, will also keep channels of communication between these parties open. Therefore this would encourage effective communication back and forth between the various groups, which in turn will lead to more positive outcomes for heritage crime cases.

Benson, B.C., 2011. Heritage Crime as the illegitimate sibling of the South African crime family. Acta Criminologica, 24(1), 83-95 http://reference.sabinet.co.za/document/EJC29055 (22 June 2015).

Bester, A., 2013. SA art market prices, trends and careful estate planning. Citadel https://www.citadel.co.za/Media/document/SA\% 20 art $\% 20$ market $\% 20$ prices $\% 20$ and $\% 20$ trends $\% 20$ $\% 20$ Alfie\%20Bester.pdf (8 July 2015).

Bradley, D., Bradley, J., Coombes, M., Grove, L., Thomas, S., And Young, C., 2012. The extent of crime and anti-social behaviour facing designated heritage assets. English Heritage http://www.english-

heritage.org.uk/content/imported-docs/p-t/researchpaper.pdf (3 October 2014).

Brodie, N., Doole J. and Watson, P. 2000. Stealing history: the illicit trade in cultural material, The McDonald Institute for Archaeological Research: Cambridge.

Crime Stats SA, 2014. Crime Stats Simplified. Crime Stats http://www.crimestatssa.com/ (9 July 2015).

Department of Arts and Culture, South Africa, 1999a. 
National Heritage Resources Act 25 of 1999. Government Gazette, 506(19974), Pretoria, Government Printers, 28 April http://www.sahra.org.za/legislations/ (3 October 2014).

Department of Arts and Culture, South Africa, 1999b. National Heritage Council Act 11 of 1999. Government Gazette, 493(19961), Pretoria, Government Printers, 23 April https://www.dac.gov.za/sites/default/files/Legislations\%20Fil es/act11-99.pdf (3 October 2014).

Dobovšek, B. And Slak, B. 2011. The Significance of Studying and Investigation Art Crime: Old Reasons, New World. Journal of Criminal Justice and Security, 13(4), pp. 392-405 http://www.fvv.um.si/rv/arhiv/20114/03_dobovsek_slak.pdf (9 July 2015).

Eck, J.E., Chainey, S., Cameron, J.G., Leiner, M. And Wilson, R.E. 2005. Mapping Crime: understanding hot spots, National Institute of Justice, Washington http://discovery.ucl.ac.uk/11291/1/11291.pdf (9 July 2015)..

FBI, N.D.a. Art Theft: It's like stealing history. Federal Bureau of Investigation http://www.fbi.gov/aboutus/investigate/vc_ majorthefts/arttheft/ (10 March 2015).

FBI, N.D.b. Art Theft: Art Crime Team. Federal Bureau of Investigation http://www.fbi.gov/about-

us/investigate/vc_majorthefts

/arttheft/art-crime-team (10 March 2015).

Grove, L., 2013. Heritocide? Defining and Exploring Heritage Crime. Public Archaeology, 12(4), 242-254 http://www.maneyonline.com/doi/pdfplus/10.1179/14655187 14Z.00000000046 (22 June 2015).

Harrison, M., 2013. Policing the past, protecting the future. Conservation Bulletin, (70), 5-7

https://content.historicengland.org.uk/ images-books/publications/conservation-bulletin-70/cb70.pdf/ (17 March 2015).

Hekman, W., 2010. Handbook on Emergency Procedures. International Council of Museums http://network.icom.museum/ fileadmin/user_upload/minisites/icms/pdfs/English.pdf (11 March 2015).

Historic England, 2015a. Welcome to Historic England. Historic England http://www.historicengland.org.uk/ (17 March 2015).

Historic England, 2015b. Alliance to Reduce Crime against Heritage (ARCH). Historic England $\mathrm{http}: / /$ www.historicengland.org.uk/ advice/caring-for-heritage/heritage-crime/arch/ (17 March 2015).

Historic England, 2015c. What is Heritage Crime? Historic England http://www.historicengland.org.uk/advice/caringfor-heritage/heritage-crime/what-is-heritage-crime-and-whatis-being-done-about-it/ (17 March 2015).

Historic England, 2015d. Police Response to Heritage Crime. Historic England http://www.historicengland.org.uk/advice/caring-forheritage/heritage-crime/what-is-heritage-crime-and-what-isbeing-done-about-it/the-role-of-the-police/ (17 March 2015).
Hollands, B., 2014. EC Museums on alert for theft of artifacts. Weekend Post, 5 April http://www.sahra.org.za/sahris/sites/default/ files/website/articledocs/Theft $\% 20$ from $\% 20 \mathrm{EC} \% 20$ museums .pdf (15 October 2014).

Hough, A. and Beckford, M., 2012. 75,000 'heritage crimes' committed in a year. The Telegraph, 19 March http://www.telegraph.co.uk/news/uknews/crime/9149420/75 000-heritage-crimes-committed-in-a-year.html (13 March 2015).

ICMS, 2010. Welcome to the ICMS website. International Council of Museums http://network.icom.museum/icms/ (10 March 2015).

ICMS/ICOM. 1993. Museum security and protection: A handbook for cultural heritage institutions, Routledge, London.

ICOM, 2014. ICOM Network. International Council of Museums http://icom.museum/ (10 March 2015).

ICOM, 2015a. Red List. International Council of Museums $\mathrm{http} / / /$ icom.museum/programmes/fighting-illicit-traffic/redlist/ (22 June 2015).

ICOM, 2015b. ICOM International Observatory on Illicit Traffic in Cultural Goods. International Council of Museums http://obs-traffic.museum/ (19 June 2015).

INTERPOL, 2015a. Works of Art. INTERPOL

http://www.interpol.int/Crime-areas/Works-of-art/Works-of$\operatorname{art}$ (10 March 2015).

INTERPOL, 2015b. Object ID. INTERPOL http://www.interpol.int/Crime-areas/Works-of-art/Object-ID (10 March 2015).

Jackson, C. , 2015. Can I bulk upload sites, recordings or objects? SAHRA.

http://www.sahra.org.za/sahris/content/can-i-bulk-uploadsites-recordings-or-objects (17 March 2015).

Korsell, L., Hedlund, G., Elwér, S. Vesterhav, D. and Heber, A., 2006. Cultural Heritage Crime - the Nordic Dimension. The Swedish National Council for Crime Prevention, Information and Publication, Stockholm http://www.bra.se/download/ 18.cba82f7130f475a2f1800024778/1312532246916/2006_2_ cultural_heritage_crime_nordic_dimension.pdf\&hotspot_redi rect=1 (13 March 2015).

Memela, S., 2008. Theft of South African Artifacts and Heritage Objects. https://www.dac.gov.za/content/theftsouth-african-artifacts-and-heritage-objects (13 October 2014).

National Treasury, South Africa, 2014. Accounting Guideline: Grap 103 Heritage Assets.

http://oag.treasury.gov.za/Publications/ 06.\%20GRAP/02.\%20Manuals/GRAP\%20Guideline\%20103 $\% 20-\% 20$ Heritage\%20Assets.pdf (17 March 2015).

Ramskjær, L. 2011. The 1970 UNESCO Convention on the Means of Prohibiting and Preventing the Illicit Import, 
Export and Transfer of Ownership of Cultural Property. History, connected conventions and Norwegian ratification and practice. In: Ramskjær, L., Nyhamar, A., Chabiera, A., and Aniszewski, M. (Eds). Stop Heritage Crime: good practices and recommendations, National Heritage Board of Poland, Warsaw, pp 35-38.

Republic of South Africa, South Africa, 2009. Second-Hand Goods Act 6 of 2009. Government Gazette, 32087,

Government Printer, Pretoria, 1 April

http://www.saps.gov.za/resource_centre/acts/downloads/juta/ shg_act_6_2009.pdf (19 June 2015).

SAHRIS, 2014. SAHRIS. SAHRA

http://www.sahra.org.za/sahris/ (11 July 2014).

SAMA, 2015a. History of SAMA. South African Museums Association http://www.sama.za.net/?page_id=69 (10 March 2015).

SAMA, 2015b. Ethics. South African Museums Association http://www.sama.za.net/?page_id=97 (19 June 2015).

SAMA, 2006. South African Museums Association Professional Standards and Transformation Indicators. South African Museums Association, Port Alfred http://www.sama.za.net/?wpfb_dl=5 (19 June 2015).

SAPA, 2012. Stolen Pretoria Art Museum artworks found. Mail and Guardian, 13 November http://mg.co.za/article/2012-11-13-stolen-pretoria-artmuseum-artworks-found (15 October 2014).

UNESCO, 2005. Convention on the Protection and Promotion of the Diversity of Cultural Expressions. Paris, October 20, 2005 http://portal.unesco.org/en/ev.php-

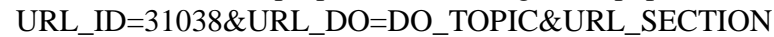
$=201 . h t m l$ (13 March 2015).

UNESCO, 2003. Convention for the Safeguarding of the Intangible Cultural Heritage. Paris, October 17, 2003, 2368 U.N.T.S. 3 http://portal.unesco.org/en/ev.php-

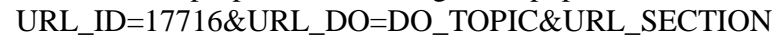
$=201 . h t m l(13$ March 2015).

UNESCO, 2001. Convention on the Protection of the Underwater Cultural Heritage. Paris, November 2, 2001. 41 I.L.M. 40 http://portal.unesco.org/en/ev.php-

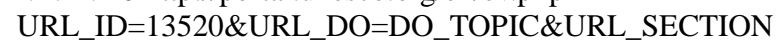
$=201 . h t m l(13$ March 2015).

UNESCO, 1999. Second Protocol to the Hague Convention of 1954 for the Protection of Cultural Property in the Event of Armed Conflict. The Hague, March 26, 1999, 2253

U.N.T.S. 212 http://portal.unesco.org/en/ev.php-

URL_ID $=15207 \&$ URL_DO=DO

TOPIC\&URL_SECTION=201.html (13 March 2015).

UNESCO, 1972. Convention Concerning the Protection of the World Cultural and Natural Heritage. Paris, November 16, 1972, 1037 U.N.T.S. 151, 27 U.S.T. 37, 11 I.L.M. 1358 http://portal.unesco.org/en/ev.phpURL ID $=13055 \&$ URL_DO=DO_TOPIC \&URL_SECTION=201.html (13 March 2015).

UNESCO, 1970. Convention on the Means of Prohibiting and Preventing the Illicit Import, Export and Transfer of
Ownership of Cultural Property. Paris, November 14, 1970, 823 U.N.T.S. 231, 10 I.L.M. 289

http://portal.unesco.org/en/ev.php-URL_ID=13039 $\& U R L \_D O=D O \_T O P I C \& U R L \_S E C T I O N=201 . h t m l(13$ March 2015).

UNESCO, 1954. Convention for the Protection of Cultural Property in the Event of Armed Conflict. The Hague, May 14, 1954, 249 U.N.T.S. 240

http://portal.unesco.org/en/ev.php-

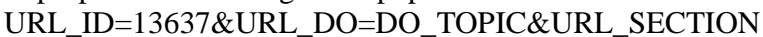
$=201 . h t m l$ (13 March 2015).

UNIDROIT, 1995. Convention on Stolen or Illegally Exported Cultural Objects. Rome, June 24, 1995, 34 I.L.M. $1322 \mathrm{http} / / /$ www.unidroit.org/instruments/culturalproperty/1995-convention (13 March 2015).

Wiltshire, N.G., 2013. The use of SAHRIS as a state sponsored digital heritage repository and management system in South Africa. In: XXIV International CIPA Symposium: Recording, Documentation and Cooperation for Cultural Heritage, Strasbourg, France, September 2-6 http://www.sahra.org.za/sahris/sites/default/files/website/artic ledocs/SAHRIS $\% 20$ CIPA $\% 202013 \% 20$ Final $\% 20$ N\% 20Wiltshire.pdf (10 October 2014). 